\title{
Teachers' positioning towards an educational innovation in the light of ownership, sense-making and agency
}

Citation for published version (APA):

Ketelaar, E., Beijaard, D., Boshuizen, E., \& Den Brok, P. J. (2012). Teachers' positioning towards an educational innovation in the light of ownership, sense-making and agency. Teaching and Teacher Education, 28(2), 273282. https://doi.org/10.1016/j.tate.2011.10.004

DOI:

10.1016/j.tate.2011.10.004

Document status and date:

Published: 01/02/2012

Document Version:

Peer reviewed version

Document license:

CC BY-NC-ND

Please check the document version of this publication:

- A submitted manuscript is the version of the article upon submission and before peer-review. There can be important differences between the submitted version and the official published version of record. People interested in the research are advised to contact the author for the final version of the publication, or visit the DOI to the publisher's website.

- The final author version and the galley proof are versions of the publication after peer review.

- The final published version features the final layout of the paper including the volume, issue and page numbers.

Link to publication

\section{General rights}

Copyright and moral rights for the publications made accessible in the public portal are retained by the authors and/or other copyright owners and it is a condition of accessing publications that users recognise and abide by the legal requirements associated with these rights.

- Users may download and print one copy of any publication from the public portal for the purpose of private study or research.

- You may not further distribute the material or use it for any profit-making activity or commercial gain

- You may freely distribute the URL identifying the publication in the public portal.

If the publication is distributed under the terms of Article 25fa of the Dutch Copyright Act, indicated by the "Taverne" license above, please follow below link for the End User Agreement:

https://www.ou.nl/taverne-agreement

Take down policy

If you believe that this document breaches copyright please contact us at:

pure-support@ou.nl

providing details and we will investigate your claim.

Downloaded from https://research.ou.nl/ on date: 26 Apr. 2023 
Ketelaar, Beijaard, Boshuizen, Den Brok | Teachers' positioning towards an educational innovation in the light of ownership, sense-making and agency

Teachers' positioning towards an educational innovation in the light of ownership, sense-making and agency

Ketelaar, E. ${ }^{\text {* }}$, Beijaard, D. ${ }^{a}$, Boshuizen, H. P. A. ${ }^{\text {b }}$ \& Den Brok, P. J. ${ }^{\text {a }}$

${ }^{a}$ Eindhoven School of Education

Eindhoven University of Technology

P.O. Box 513

5600 MB Eindhoven

The Netherlands

Tel: +31(0)402473095

E. Ketelaar e.ketelaar@gmail.com

D. Beijaard d.beijaard@tue.nl

P.J. den Brok p.j.d.brok@tue.nl

${ }^{\mathrm{b}}$ Centre for Learning Sciences and Technologies

Open University in the Netherlands

P.O. Box 2960

6401 DL Heerlen

The Netherlands

H.P.A. Boshuizen els.boshuizen@ou.nl

*Corresponding author 
Ketelaar, Beijaard, Boshuizen, Den Brok | Teachers' positioning towards an educational innovation in the light of ownership, sense-making and agency

\begin{abstract}
The positioning of eleven teachers towards an innovation was studied in the light of ownership, sense-making and agency. Semi-structured and video-stimulated interviews were used for data collection. The findings show that these three concepts are useful for describing similarities and differences between teachers in terms of their positioning towards the innovation. Considerable differences were found between teachers regarding their ownership, sense-making, and agency. Exploring the relations between these concepts revealed that a high degree of agency often went together with a high degree of ownership, but seemed to be moderated by the sense-making process.
\end{abstract}

Keywords: ownership; sense-making; agency; educational innovation; coaching role. 
Ketelaar, Beijaard, Boshuizen, Den Brok | Teachers' positioning towards an educational innovation in the light of ownership, sense-making and agency

\section{Introduction}

As teachers are often not involved in the design of educational innovations, their reactions to the implementation of an innovation largely depend on whether they perceive their identities as being reinforced or threatened by the proposed changes (Van Veen \& Sleegers, 2006). For some teachers the innovation might fit perfectly within their beliefs about teaching, but for other teachers the innovation might conflict with what they personally desire in their work and what they consider good education. In the latter case, teachers' identities can be affected, as it may lead to tensions between what one personally values in teaching and what is externally demanded (Beijaard, Meijer, \& Verloop, 2004; Day, Sammons, Stobart, Kington, \& Gu, 2007). Yet, in both cases it is not a matter of simply accepting or rejecting what is being imposed: teachers actively position themselves in relation to an innovation (Spillane, Reiser, \& Reimer, 2002; Vähäsantanen \& Eteläpelto, 2009). They make deliberate choices (Coldron \& Smith, 1999) and compare their personal beliefs, desires and values in work with the characteristics and demands of the proposed changes (Spillane et al., 2002). Three identity-related concepts seem to play an important role in this process of positioning oneself in relation to an innovation, namely ownership, sense-making and agency (cf. Beijaard, 2009). In this study, these concepts are used as a lens to see how teachers position themselves as regards a specific educational innovation. The central research question driving this study is therefore: how are ownership, sense-making, and agency manifested in teachers' positioning towards an educational innovation?

Ownership, sense-making and agency have in common that they are closely related to teachers' identities, yet all in a somewhat different way. Ownership can be seen more as a facilitator of expressing who one is as a teacher and what one finds important (Pierce, Kostova, \& Dirks, 2001). Sense-making involves the interaction between one's identity and the innovation, resulting in maintenance or alteration of one's identity (Luttenberg, Imants, Van Veen, \& Carpay, 2009). Agency, at last, might be seen as a vehicle to give direction to one's career as a teacher and stay true to oneself (cf. Vähäsantanen, Hökkä, Eteläpelto, Rasku-Puttonen, \& Littleton, 2008). By investigating teacher change through the lens of these three concepts, we aim at gaining better understanding of how teachers position themselves towards an innovation. It is hoped that this contributes to current views on teacher change in the context of educational innovations, and provides insights into the role that ownership, sense-making and agency play in it. The findings will have practical implications for teachers and school leaders, as they help understand differences between teachers' positioning towards educational innovations. 
Ketelaar, Beijaard, Boshuizen, Den Brok | Teachers' positioning towards an educational innovation in the light of ownership, sense-making and agency

\section{Context of the study: teachers' coaching role in innovative secondary vocational education}

This study has been conducted in the context of secondary vocational education (SVE) in the Netherlands. The vocational trainings in Dutch SVE vary in duration (from 1 year up to 4 years), difficulty (from level 1 to level 4 , with level 4 being the most difficult), and study-route (school-based: between $20 \%$ and $60 \%$ includes practical/workplace training and the remaining time is spent at school; work-based: at least $60 \%$ includes practical/workplace training and the remaining time is spent at school). The student population is therefore rather diverse, differing in age and abilities. SVE prepares students for starting their working career. Graduates on the highest level of SVE have access to the bachelor programme on higher vocational education.

As professions and jobs were changing rapidly, during the late 1990s the SocialEconomic Council and the Education Council advised the Dutch government to revise the content and design of secondary vocational education (SVE) in the Netherlands (Dutch Inspectorate of Education, 2007). The reform was aimed at improving the transition from school to the labour market. Furthermore, it should prepare students for lifelong learning, so that they can continue to develop themselves in their future jobs and react to innovations and developments in their field of work (Biemans, Nieuwenhuis, Poell, Mulder, \& Wesselink, 2004; Biemans et al., 2009; Day et al., 2007). The idea was to provide students with self-regulated learning skills that can help them direct their own learning processes (Zimmerman, 2002; Zsiga \& Webster, 2007). This trend is also noticeable in other contexts and countries (e.g. Le Cornu \& Peters, 2005; Struyven \& De Meyst, 2010; Vermunt \& Verloop, 1999), especially in vocational education (Nickolaus, Knoll, \& Gschwendtner, 2007; Velde, 1999; Yu \& Boulton-Lewis, 2008). From 2004 onwards, several SVE schools in the Netherlands started experimenting with redesigning their learning environment and from August 2010, every SVE school was obliged to have started with the implementation (Dutch Inspectorate of Education, 2007). The extent to which the implementation took place, however, differs considerably between schools and even within schools (De Bruijn \& Leeman, 2011).

For teachers, this innovation requires a different role in the classroom. Besides their role as a subject expert, they are expected to take on a coaching role (Biemans et al., 2004; Biemans et al., 2009; Wesselink et al., 2007; Yu \& Boulton-Lewis, 2008). The aim of the coaching role is to support and guide students' learning processes, and in particular their self-regulated and independent learning (e.g. Bakker, 2008; De Bruijn \& 
Ketelaar, Beijaard, Boshuizen, Den Brok | Teachers' positioning towards an educational innovation in the light of ownership, sense-making and agency

Leeman, 2011). In this study, we concentrate on the teacher's coaching role in the classroom, that is, in interaction with students who are working on tasks, which can be individually, in cooperative groups, or in a whole-class situation. The teacher in the coaching role can be seen as a facilitator of the students' learning processes, anticipating the different (learning) needs of individual students (Iredale \& Schoch, 2010). In a previous study, we investigated SVE teachers' perceptions of the coaching role (Ketelaar, Beijaard, Den Brok, \& Boshuizen, 2009). Most teachers who participated in that study had perceptions of the coaching role that were (to some extent) in line with the aims of innovative SVE, although there were also several aspects which seemed underexposed. Promoting and supporting students' meta-cognitive skills, creating a positive learning and working atmosphere, and providing guidance and active support were common themes in the teachers' perceptions. However, we also detected considerable variety in the perceptions of these teachers. In the present study these differences are further investigated in terms of how SVE teachers position themselves towards the coaching role in the light of ownership, sense-making and agency.

\section{Conceptual framework}

\subsection{Ownership}

In this study ownership is understood as a mental or psychological state of feeling owner of an innovation, which develops through the teacher's mental and/or physical investment in it (cf. Breiting, 2008; Pierce et al., 2001). Although teachers feeling ownership towards an innovation is often mentioned as important for its success, ownership seems to be an under-researched concept in the context of educational innovations (Breiting, 2008). Feeling ownership is assumed to lead to integration of the innovation in teachers' working routines (Bergen \& Van Veen, 2004) and a continuation of the change process in the future, even when the initiator or any other extrinsic motivation is no longer present (Struckman \& Yammarino, 2003). Only if teachers support the ideas of the innovation, and feel the urge or necessity for change, are they willing to invest time and energy in it (Van den Berg \& Geurts, 2007). By investing in the creation and development of an innovation, the teacher can identify with it. According to Pierce et al. (2001), 'people use ownership for the purpose of defining themselves, expressing their self-identity to others, and ensuring the continuity of the self across time' (p.300). Teachers feeling a high degree of ownership towards an innovation communicate about it and express their identification with it (Pierce, Kostova, \& Dirks, 2003). In short, feeling ownership towards an innovation can be 
Ketelaar, Beijaard, Boshuizen, Den Brok | Teachers' positioning towards an educational innovation in the light of ownership, sense-making and agency

recognised by teachers' support for the innovation, their sense of the necessity for it and their communication about it.

\subsection{Sense-making}

When teachers are confronted with an educational innovation, they make sense of it in the light of their own knowledge, beliefs and experiences, the situation in which they find themselves, and the design and message of the policy for implementing the innovation (Spillane et al., 2002). Teachers' sense-making of an innovation can be defined as the interaction between their own frame of reference and the perception of the situational demands that are inherent to innovations, resulting in the personal interpretation of innovations' (Luttenberg et al., 2009, p. 446). This means that sensemaking is more than simply interpreting a message. It is an active cognitive and emotional process in which a person attempts to fit the new information into existing knowledge and beliefs (Spillane et al., 2002; Van Veen \& Lasky, 2005). Luttenberg et al. (2009) describe four types of sense-making, which are determined by (a) the amount of congruence between the teacher's frame of reference and the situational demands of the innovation and (b) the dominance of either the teacher's frame of reference or the situational demands of the innovation during the sense-making process.

The first type of sense-making is assimilation, which means that the teacher uses his or her own frame of reference in the sense-making process and adapts the new ideas in such a way that they fit into the existing frame. This results in a variation within his or her frame of reference. The second type of sense-making is accommodation, in which the teacher transforms his or her own frame of reference in such a way that it fits in with the situational demands. The situational demands are predominant in this type. The third type defined is toleration, whereby the teacher accepts the new situational demands but at the same time maintains his or her own frame of reference, which results in different perceptions within the teacher. The last type of sense-making is distantiation, where the teacher totally rejects the situational demands and continues to use his or her initial frame of reference. Different combinations of the four types of sense-making can be found within one teacher (cf. Luttenberg at al., 2009).

\subsection{Agency}

Agency is the extent to which someone feels in control of his or her own actions (Beijaard, 2009; Metcalfe \& Greene, 2007). Teachers who experience agency within their work feel in control of the choices they make within their work and that these choices are based upon their own goals, interests and motivations (Vähäsantanen et al., 2008). 
Ketelaar, Beijaard, Boshuizen, Den Brok | Teachers' positioning towards an educational innovation in the light of ownership, sense-making and agency

Agency is thus shaped by both the teacher and the school context (Lasky, 2005), as teachers need to experience a certain amount of autonomy and room for negotiation within their school to make their own choices (Beijaard, 2009; Coldron \& Smith, 1999). It is important for teachers to experience agency within their work at least to some extent, as it plays a role in the development and maintenance of their professional identity (Beijaard, 2009). When teachers are confronted with an educational innovation they are expected to adjust their working routines according to the innovation. The degree to which teachers experience agency within their work will probably influence their response to the innovation. For instance, teachers with a high degree of agency and beliefs conflicting with those of the innovation might use their agency to offer resistance to the innovation (Sannino, 2010). On the other hand, when the goals a teacher values correspond with the goals of the innovation, teachers' sense of agency can be increased (Marshall \& Drummond, 2006). In sum, to identify teachers' experiences of agency within their work, it should become clear what their own goals are, how these differ from the goals of their school, and why and how they make choices for certain goals.

\subsection{Research questions}

The following research questions have been formulated to study teacher change with regard to the coaching role through the lens of ownership, sense-making, and agency.

1. To what degree do teachers feel ownership towards the coaching role?

2. How do teachers make sense of the coaching role?

3. To what degree do teachers experience agency within their work as a teacher?

4. How are teachers' ownership, sense-making and agency related?

\section{Method}

\subsection{Participants}

Eleven teachers from two secondary vocational education (SVE) schools in the Netherlands participated in this study. After an introduction and explanation of the study in a team meeting, teachers could agree to participate. Initially, fourteen teachers subscribed, but three of them decided to withdraw after the first interview, because they thought participation was too time-consuming. These three teachers were all from the same school (school 2). The interview data from these teachers were not included in the analysis. All teachers participated on a voluntary basis and their anonymity was guaranteed. 
Ketelaar, Beijaard, Boshuizen, Den Brok | Teachers' positioning towards an educational innovation in the light of ownership, sense-making and agency

Two of the eleven participants were female and nine male. All teachers worked in the technology education sector. This sector is dominated by male teachers, which explains the predominance of males in this study. On average participants were 42.9 years old, ranging from 34 to 55 . They had on average 10.4 years of experience as SVE teachers, with a minimum of 1.5 and a maximum of 25 years. Table 1 contains general characteristics of the participants, aliases being used for reasons of anonymity. Four of the 11 teachers were from school 1, all of them working in the same department ("mobility and logistics"). The other seven teachers were from school 2, from two different departments ("mobility and logistics" and "construction techniques").

Table 1

General characteristics of the 11 participants

\begin{tabular}{|c|c|c|c|c|c|c|}
\hline School & Department & Alias & Gender & Age & $\begin{array}{c}\text { Years of } \\
\text { experience }\end{array}$ & Subject \\
\hline \multirow[t]{4}{*}{1} & \multirow[t]{4}{*}{$\begin{array}{l}\text { Mobility and } \\
\text { logistics }\end{array}$} & George & Male & 55 & 25 & $\begin{array}{l}\text { Automotive and } \\
\text { electro technology }\end{array}$ \\
\hline & & Alice & Female & 41 & 20 & $\begin{array}{l}\text { Mathematics, } \\
\text { physics, chemistry }\end{array}$ \\
\hline & & Tom & Male & 38 & 4 & $\begin{array}{l}\text { Two-wheel } \\
\text { engineering }\end{array}$ \\
\hline & & Eric & Male & 34 & 9 & $\begin{array}{l}\text { Two-wheel } \\
\text { engineering }\end{array}$ \\
\hline \multirow[t]{7}{*}{2} & \multirow[t]{4}{*}{$\begin{array}{l}\text { Construction } \\
\text { technology }\end{array}$} & Hugo & Male & 37 & $2(+9)^{a}$ & $\begin{array}{l}\text { Construction } \\
\text { technology }\end{array}$ \\
\hline & & Ben & Male & 45 & 1.5 & $\begin{array}{l}\text { Woodworking and } \\
\text { furniture }\end{array}$ \\
\hline & & James & Male & 43 & 18 & Painting \\
\hline & & Steven & Male & 51 & 10 & $\begin{array}{l}\text { Construction } \\
\text { technology; } \\
\text { woodworking and } \\
\text { furniture }\end{array}$ \\
\hline & \multirow[t]{3}{*}{$\begin{array}{l}\text { Mobility and } \\
\text { logistics }\end{array}$} & Suzan & Female & 44 & 3 & $\begin{array}{l}\text { Citizenship } \\
\text { education }\end{array}$ \\
\hline & & Mark & Male & 35 & 1.5 & $\begin{array}{l}\text { Automotive } \\
\text { technology }\end{array}$ \\
\hline & & Jon & Male & 49 & 20 & $\begin{array}{l}\text { Mathematics and } \\
\text { economics }\end{array}$ \\
\hline
\end{tabular}

a This teacher had nine years of experience in other educational settings before he became an SVE teacher.

\subsection{Schools}

The two schools are both so-called "regional educational centres", each educating approximately 10000 students, within the sectors Care and Welfare, Business and Economics, and Technology. These sectors are subdivided into departments, offering a broad range of vocational trainings. The teachers from the "mobility and logistics" 
Ketelaar, Beijaard, Boshuizen, Den Brok | Teachers' positioning towards an educational innovation in the light of ownership, sense-making and agency

department of school 1 describe their school as innovative with regard to the redesign of SVE. Furthermore, they experience factors which are supportive in the context of an educational innovation considerably present within their school. The teachers from school 2 are from two different departments, but are both led by the same head of department. Teachers from these departments describe their school as moderately innovative with regard to the redesign of SVE and they experience factors which are supportive in the context of an educational innovation reasonably present within their school.

\subsection{Instruments}

To obtain a complete picture of how the concepts ownership, sense-making and agency are manifested in teacher change towards a coaching role, multiple methods were used for the data collection (cf. Yin, 2003). Combining the data collected with different instruments can be helpful to develop a comprehensive view of complex concepts such as these three (Meijer, Verloop, \& Beijaard, 2002). A semi-structured interview and a video-stimulated interview were used for data collection. The semi-structured interview was conducted to study teachers' feelings of ownership towards the coaching role, their sense-making, and their agency within their work, on a general level. The videostimulated interview was held to study these three concepts on a level closely related to the teachers' behaviour in interaction with students (cf. Lyle, 2003).

\subsubsection{Semi-structured interview}

Several general questions about the teachers' background and work were asked, such as their age, years of experience as an SVE teacher, previous working experience, and the subject they teach. The central part of the interview was set up around the concepts of ownership, sense-making, and agency. For each concept several indicators were derived from the literature. The indicators were:

- Ownership: support for coaching role, sense of necessity for coaching role, and communication about coaching role;

- Sense-making: matching between teachers' frame of reference about coaching role and the frame of reference of the innovation, and dominance of either frame of reference;

- Agency: teachers' goals, school goals, differences and similarities between teachers' goals and school goals, choices teachers make, and activities performed to reach goals. 
Ketelaar, Beijaard, Boshuizen, Den Brok | Teachers' positioning towards an educational innovation in the light of ownership, sense-making and agency

These indicators were translated into concrete questions. Table 2 shows each concept with its indicators and for each indicator an example question. During the interview follow-up questions were asked if elaboration or clarification was required.

Table 2

Sample questions of the semi-structured interview

\begin{tabular}{|c|c|c|}
\hline Concepts & Indicators & Sample questions \\
\hline \multirow[t]{3}{*}{ Ownership } & Support & $\begin{array}{l}\text { What do you think about the statement that } \\
\text { the role of the teacher is changing from that } \\
\text { of knowledge transmitter to that of coach? }\end{array}$ \\
\hline & Sense of necessity & $\begin{array}{l}\text { What do you think is the reason the coaching } \\
\text { role is becoming more important? To what } \\
\text { extent do you agree with that reason? }\end{array}$ \\
\hline & Communication & $\begin{array}{l}\text { Do you ever talk with your colleagues about } \\
\text { how they put the coaching role into practice? } \\
\text { Do you take the initiative for such } \\
\text { conversations? }\end{array}$ \\
\hline \multirow[t]{2}{*}{ Sense-making } & $\begin{array}{l}\text { Matching frame of } \\
\text { reference }\end{array}$ & $\begin{array}{l}\text { What image do you have about a teacher } \\
\text { teaching in a coaching way? What kind of } \\
\text { activities does he or she undertake? }\end{array}$ \\
\hline & $\begin{array}{l}\text { Dominance frame of } \\
\text { reference }\end{array}$ & $\begin{array}{l}\text { Do you think that your image of the coaching } \\
\text { role, and the way you put it into practice, } \\
\text { corresponds with what is expected of you } \\
\text { regarding the redesign of SVE? Has it always } \\
\text { been like that? }\end{array}$ \\
\hline \multirow[t]{5}{*}{ Agency } & Teacher's goals & $\begin{array}{l}\text { What are your goals in your work as a } \\
\text { teacher? }\end{array}$ \\
\hline & School goals & What are the main goals of this school? \\
\hline & $\begin{array}{l}\text { Teacher's goals vs. } \\
\text { school goals }\end{array}$ & $\begin{array}{l}\text { To what extent do your personal goals } \\
\text { correspond with the main goals of the } \\
\text { school? }\end{array}$ \\
\hline & Choices & $\begin{array}{l}\text { To what extent do you feel that there is room } \\
\text { to pursue your own goals in your work? }\end{array}$ \\
\hline & Activities & $\begin{array}{l}\text { What do you do to make sure you can reach } \\
\text { the goals that you have in your work? }\end{array}$ \\
\hline
\end{tabular}

\subsubsection{Video-stimulated interview}

Two to three months after the semi-structured interview, for every teacher approximately 1.5 hours of lessons were video-taped by the first author. Permission for 
Ketelaar, Beijaard, Boshuizen, Den Brok | Teachers' positioning towards an educational innovation in the light of ownership, sense-making and agency

filming in the classrooms was obtained from both school leaders and participating teachers. Students were informed about the purpose of the filming and were given the possibility to position themselves beyond reach of the camera. The first author followed the following procedure to select fragments of the video-taped lesson that served as input for a video-stimulated interview (VSI). The video was divided into fragments. A fragment consisted of an interaction between the teacher and an individual student, a small group of students, or the whole class. A new fragment started when a different interaction took place. Therefore, the length of a fragment could range from a few seconds to several minutes. An observation scheme was used to score per fragment the activities the teacher showed. Three or four fragments were then selected as input for the VSI. The selected fragments either showed a series of teacher activities that was observed several times during the lesson, or a series of activities that was observed only once. By doing this, it was tried to include in the VSI as much as possible of the teacher's repertoire shown in the lesson.

Several days after recording the lesson, the VSI was conducted. The VSI was also set up around the concepts of ownership, sense-making, and agency, but now closely related to the teacher's behaviour in interaction with students. During the VSI, the teacher was first shown one of the selected fragments, after which several questions were asked (cf. Lyle, 2003). Examples of the questions are: 'Is this behaviour typical of you as a teacher and how you interact with your students?', 'What were you aiming for in this fragment?', and 'Is this behaviour in line with the coaching role? Why?'. When all questions were answered and the teacher had nothing more to add about the particular fragment, the next fragment was shown, until all selected fragments had been discussed.

\subsection{Data analysis}

The data were analysed within-case and cross-case. For both approaches, following Miles and Huberman (1994), the data were analysed by a process of data reduction, data display, and conclusion drawing and verification.

\subsubsection{Within-case analysis}

A matrix was developed to display the data of each participant systematically. The indicators that guided the semi-structured interview represented the rows of the matrix. The columns represented the data from the semi-structured interview, the data from the video-stimulated interview and representative quotes from both interviews (see Table 3 for an example). Data entry for each case comprised several steps. While we listened to the audio-taped semi-structured interview, the answer to each question was 
Ketelaar, Beijaard, Boshuizen, Den Brok | Teachers' positioning towards an educational innovation in the light of ownership, sense-making and agency

summarised and entered in the matrix with the appropriate indicator (for example, 'support for coaching'). A representative quote was added when appropriate. Similarly the VSI was analysed. As the teachers often elaborated on specific events which were not related to their coaching role (for instance, by giving extensive clarification about a certain student's background and history), only the data that applied to their ownership, sense-making and agency were used. These data were summarised and added to the matrix with the indicator to which they applied. If applicable, representative quotes from the video-stimulated interview were added to the matrix.

Table 3

Illustration of part of the analysis matrix of one participant

\begin{tabular}{|c|c|c|c|}
\hline \multicolumn{4}{|l|}{ Ownership } \\
\hline Indicators & $\begin{array}{l}\text { Summary semi- } \\
\text { structured interview }\end{array}$ & $\begin{array}{l}\text { Video-stimulated } \\
\text { interview }\end{array}$ & Quote \\
\hline $\begin{array}{l}\text { Spirit and } \\
\text { support for } \\
\text { coaching }\end{array}$ & $\begin{array}{l}\text { Fit of coaching role: } \\
\text { When the electronic } \\
\text { learning environment } \\
\text { was implemented and } \\
\text { they stopped whole- } \\
\text { class instructions, he } \\
\text { felt like he had come } \\
\text { home. The coaching } \\
\text { role fits him and his } \\
\text { previous working } \\
\text { experiences. }\end{array}$ & $\begin{array}{l}\text { He's known as } \\
\text { somebody that never } \\
\text { gives answers, but } \\
\text { always asks questions } \\
\text { in return. He's } \\
\text { enthusiastic about the } \\
\text { coaching role. Sees } \\
\text { himself as a guide. Is } \\
\text { still looking for the } \\
\text { balance between } \\
\text { guiding and teaching. }\end{array}$ & $\begin{array}{l}\text { 'My colleague is a } \\
\text { teacher in heart and } \\
\text { soul, so when he } \\
\text { enters the classroom } \\
\text { all students keep } \\
\text { silent. And I am } \\
\text { originally a guide, so } \\
\text { when I enter the } \\
\text { classroom everybody } \\
\text { starts talking' (video- } \\
\text { stimulated interview). }\end{array}$ \\
\hline
\end{tabular}

To be able to draw conclusions, for each participant an analytic text or portrait was drawn from the matrices (Miles \& Huberman, 1994). The portrait reflected the teacher's feelings of ownership towards the coaching role, how he or she made sense of it, and his or her experience of agency within the work. The portrait was illustrated with representative quotes from both interviews. An example of such a teacher portrait is that of Eric:

The teacher felt a high degree of ownership towards the coaching role. He thinks the coaching role fits him and he likes it to learn more about it. Also, he does not see it as a change, but as something that has always been important. He finds it very important to give students individual attention. He communicates a lot with his colleagues about the coaching role and tries to convince them of his standpoints. "That is just in my nature. Especially when I don't understand somebody, why somebody is doing something, then I either want to understand him, or I'd like him to do it the way I want it" (semi-structured interview). Besides 
Ketelaar, Beijaard, Boshuizen, Den Brok | Teachers' positioning towards an educational innovation in the light of ownership, sense-making and agency

that, he also finds it important that there is a balance between his coaching role and his expert role.

He seemed to make sense of the coaching role mainly through assimilation. Coaching has always been important and has hardly anything to do with the redesign of SVE. He sees coaching as creating a group with a shared goal, with a lot of attention to individual students, by motivating, guiding, and following them, and by adjusting his approach to individual students' needs. Colleagues mostly see the coaching role as less extensive and they invest less in creating a group. For him coaching and the innovation of SVE are largely independent. The innovation provides him with some directions but not precisely how to put them into practice.

The teacher experienced a high degree of agency within his work as a teacher. He finds it important to be able to pursue his personal goals as a teacher and actively takes room to do so. Also, he undertakes activities to develop himself. It frustrates him when he cannot reach his goals. The school provides him with freedom and room, but he also experiences some hindrances in working according to his personal goals.

\subsubsection{Cross-case analysis}

For the cross-case analysis another matrix was developed to display the portraits of all 11 participants systematically together. The participants represented the rows of the matrix and the concepts ownership, sense-making, and agency represented the columns. The portraits were divided into three subparts (representing ownership, sensemaking, and agency) and entered in the cells of the matrix. After that, each of the three concepts was studied separately, the teachers with a similar outcome regarding the concept being grouped and similarities and differences both within and between these subgroups identified. Finally, the relations between the concepts were studied by contrasting and comparing the teachers with regard to all three concepts.

\subsubsection{Reliability}

The following were undertaken to ensure reliability of the data analysis (cf. Yin, 2003). The first author analysed all data and made the process verifiable for the other authors. Each step taken in the analysis has been discussed in detail by the four authors. After agreement on the previous step, a decision on a follow-up step was taken. Furthermore, the matrices, teacher portraits and the results were illustrated with representative quotes of the data from both interviews. 
Ketelaar, Beijaard, Boshuizen, Den Brok | Teachers' positioning towards an educational innovation in the light of ownership, sense-making and agency

\section{Results}

The teachers could be divided into three subgroups regarding the degree to which they felt ownership towards the coaching role, namely high, moderate, and low. Use of the four types of sense-making described by Luttenberg et al. (2009) meant the teachers could be divided into five subgroups in terms of how they made sense of the coaching role. Furthermore, they also could be divided into three subgroups regarding the degree to which they experienced agency within their work as a teacher, namely high, moderate, and low. Table 4 displays an overview of the results per concept for each participant. In the following these results are further explicated per research question.

Table 4

Overview of the results per participant and per concept

\begin{tabular}{llll}
\hline & Ownership & Sense-making & Agency \\
\hline George & High & Assimilation - Accommodation & Moderate \\
Alice & Moderate & Assimilation - Distantiation & Moderate \\
Tom & High & Assimilation & High \\
Eric & High & Assimilation & High \\
Hugo & Moderate & Assimilation - Distantiation & Moderate \\
Ben & Low & Toleration - Distantiation & Low \\
James & High & Assimilation & High \\
Steven & High & Accommodation & Moderate \\
Suzan & High & Assimilation & High \\
Mark & Low & Toleration - Distantiation & Moderate \\
Jon & High & Assimilation - Accommodation & High \\
\hline
\end{tabular}

\subsection{Teachers' feelings of ownership towards the coaching role}

Seven teachers felt a high degree of ownership towards the coaching role, namely George, Tom, Eric, James, Steven, Suzan and Jon. With regard to support for the innovation, they all indicated that the coaching role fits them very well and they feel comfortable in this role. George, Steven and Suzan would not even describe themselves as a teacher, but rather as a guide, coach, or parent figure. Eric, Tom, James and Suzan mentioned that, for themselves, they do not see the coaching role as a change, as it has always been important and they have always had that role. Suzan said:

Finally we've understood it! (semi-structured interview).

Furthermore, all of them pointed out that coaching better suits the students or that the students need such an approach, indicating a sense of necessity for the coaching role. 
Ketelaar, Beijaard, Boshuizen, Den Brok | Teachers' positioning towards an educational innovation in the light of ownership, sense-making and agency

They are all willing to communicate with their colleagues about the coaching role, but feel also hindered in this, for example because their colleagues are not receptive to it.

Two teachers, Alice and Hugo, felt a moderate degree of ownership towards the coaching role. They both indicated that a coaching role suits them, but that it depends on the setting. Alice finds coaching mainly important in her role as student mentor and Hugo in project-based working settings. Both found it important that there remains enough room for knowledge transmission and their subject. On the other hand, both think that the students need to be approached in a coaching way, at least partly. Hugo pointed out he sometimes communicates with his colleagues about how they approach the students. Alice hardly communicates at all with her colleagues about the approaches they use in their lessons:

It is more talking about students, like that one is doing well and that one isn't doing anything, more in that manner. Or, that student doesn't belong here; we should make sure to find him or her a better place. That kind of things. But about how we approach students we actually hardly discuss. Because you also know already that one teacher has a totally different approach than the other (videostimulated interview).

Finally, Ben and Mark felt a low degree of ownership towards the coaching role. They show little support for the innovation. Although both pointed out that there is more to it than just knowledge transmission and that interaction with students is important, they still attach great importance to knowledge transmission and development of knowledge. A change towards a coaching role is not a necessity for them. They find their students need whole-class instructions and guidance, because they lack independence and prior knowledge. Mark's preference for a whole-class approach is well reflected in the following quotation:

How do you want to bring coaching into practice? When you are with a group of 20 students and you are able to regulate the discussion that arises, then you are present yourself. Actually you are doing the same then, just with 20 people at the same time. You might also get 20 different opinions, but if you do it in a regulated way, you are actually also coaching and guiding and including their future work field, just as much as if you do it one-on-one (semi-structured interview).

Ben only communicates with colleagues about the coaching role on their initiative, and Mark's communication with colleagues is mainly about whole-class situations. 
Ketelaar, Beijaard, Boshuizen, Den Brok | Teachers' positioning towards an educational innovation in the light of ownership, sense-making and agency

Taken together, for teachers feeling a higher degree of ownership the coaching role seemed to belong to their teacher identity, which was apparently not the case with teachers feeling a lower degree of ownership. Also, teachers feeling a higher degree of ownership seemed to attach greater importance to it, as much for themselves as for their students, whereas teachers feeling a lower degree of ownership find coaching is not (always) suitable for their student population.

\subsection{Teachers' sense-making of the coaching role}

Tom, Eric, James and Suzan seemed to make sense of the coaching role mainly through assimilation. There was correspondence between their own frame of reference and that of the innovation. They let their own frame of reference dominate, however, by mainly interpreting the coaching role from their own beliefs. They all see it as a way of working with students which is generally applicable and does not depend on a certain setting. It seems that they internalised the coaching role and that it is an approach they automatically switch over to. James phrased it as follows:

So I'm all the time in all kinds of roles and I'm constantly looking for ways to coach. So coaching is much more than telling a student "www dot something and you'll find it' (semi-structured interview).

These four teachers find it important to create a safe learning environment, give their students individual attention and adapt their approach to the individual needs of each student. All four mentioned that their beliefs about the coaching role are different from their colleagues' beliefs, who often see it less extensive. Finally, for these four teachers their beliefs about the coaching role are mostly independent of the redesign of SVE, as they find for instance that the innovation lacks certain features they find important or that it is unclear how to put the directions provided about innovating SVE into practice.

Two teachers, George and Jon, seemed to make sense of the coaching role mainly through assimilation and (a will towards) accommodation. There was correspondence between their own frame of reference and that of the innovation. They interpret the coaching role from their own beliefs, but indicated also that they have changed. Jon observed:

I developed in the past 20 years from transmitting subject matter and explaining as much as possible, to this. And this suits me better I think. That transition just went gradually. Also the first year that you teach, you have a conversation now and then with students with a problem, or without a problem. Those are nice 
Ketelaar, Beijaard, Boshuizen, Den Brok | Teachers' positioning towards an educational innovation in the light of ownership, sense-making and agency

conversations and then you can better understand those students and you hope to be able to advise them. And slowly and surely that expands (semi-structured interview).

The other teacher, George, said he is willing to accommodate more, but does not know how, as he finds the frame of reference of the innovation rather unclear. Like the four teachers described above, both Jon and George see the coaching role as a continuous, ever-present role. Both find it important to pay individual attention to students, and that students really think about the subjects and learn how to put them into practice, instead of learning them by heart. Jon in particular found it important to pay attention to students' study progress, attendance and future orientations. Jon and George have a different view of the coaching role from their colleagues. Yet Jon seems to experience this difference to a larger extent than George.

One teacher, Steven, seemed to make sense of the coaching role mainly through accommodation. He said that through schooling he learnt a lot about innovative SVE and the coaching role and therefore has changed a lot compared with when he started working as a teacher, but he is also still searching for how to put the coaching role into practice. He also sees coaching as a continuous, ever-present role. He finds it important to create a safe and stimulating learning environment, with attention to both the student as a person and the subject he teaches. He finds his beliefs about the coaching role are not in correspondence with most colleagues, who interpret it more narrowly than he does.

Alice and Hugo seemed to make sense of the coaching role through assimilation and some degree of distantiation. For both of them their expert role is to some extent dominant, but differs in how it is. With regard to Hugo there was correspondence between his own frame of reference and that of the innovation, but only when students work in a project-based setting. He finds the frame of reference of the innovation somewhat unclear, however, as he explained in the following:

Then I think I do really well. But whether that is what they want with the redesign of SVE, I don't know (semi-structured interview).

He sees the coaching role as creating an open and stimulating learning environment, with attention to the students and the work they do. In a whole-class setting he makes sense of the coaching role mainly through distantiation, as he is then mostly teaching and not coaching. He finds he has different beliefs about the coaching role than most of his colleagues, who interpret it less comprehensively than he does. With regard to Alice, 
Ketelaar, Beijaard, Boshuizen, Den Brok | Teachers' positioning towards an educational innovation in the light of ownership, sense-making and agency

there seemed to be only partial correspondence between her own frame of reference and that of the innovation, as her expert role and subject were often very dominant in her beliefs about the coaching role. She sees coaching mainly as guiding and supporting students' thinking process when working on tasks. This is something she had to learn, she explained:

Yes, I had to learn this and some years ago I much easier just gave them the answer immediately, or this or that. I think nowadays you see this much more, that most of the time you give them little steps to get to the end product. So that you let them think for themselves (video-stimulated interview).

She thinks that her colleagues interpret the coaching role in the same way she does.

Two teachers, Ben and Mark, seemed to make sense of the coaching role mostly through toleration and distantiation, as their own frames of reference hardly seemed to correspond to the frame of reference of the innovation. On the one hand, their sensemaking process seemed a matter of toleration, as both indicated that there is more to their lessons than just whole-class instructions, but they interpret the coaching role in the classroom from the perspective of their expert role and the subject they teach, or treat it as a role outside the classroom. They see the coaching role as the 'new name' for the student counsellor who has one-on-one conversations with students about things other than subject matter. Within the classroom, they see coaching mainly as guiding and supporting students' thinking process when working on tasks. One of them, Mark, prefers to create a learning environment which is mostly directed at whole-class and group interaction, instead of being directed at individual students. On the other hand, how they make sense of the coaching role seemed to be a matter of distantiation, as both indicated they think not much will change in education, which they also prefer. Ben said, for instance:

How they talk about it, yeah, that is a bit like, yeah, in the future we are only allowed to talk with our students and we're not allowed anymore to explain them anything, so to speak, because they have to search for information themselves. I don't believe in that, but that is the image I get a bit from it. But again, I don't think much will change (semi-structured interview).

Both teachers said their beliefs about the coaching role correspond with the beliefs of their colleagues, although Mark said his colleagues do not see their own way of teaching as coaching. 
Ketelaar, Beijaard, Boshuizen, Den Brok | Teachers' positioning towards an educational innovation in the light of ownership, sense-making and agency

Overall, several results stood out with regard to the sense-making processes of these teachers. First, teachers who mainly make sense of the coaching role through assimilation and/or accommodation interpret the coaching role as a continuous, everpresent role, which is not the case with the teachers whose sense-making process can be (partly) typified as toleration and/or distantiation. Second, the 'assimilation and/or accommodation teachers' indicated that their beliefs about the coaching role are mostly not in correspondence with the beliefs of their colleagues. The 'toleration and/or distantiation teachers', conversely, think their colleagues have the same beliefs about coaching that they have. Third, quite a number of teachers who make sense through assimilation and/or accommodation said that they find the frame of reference of the innovation rather unclear.

\subsection{Teachers' experiences of agency within their work}

Tom, Eric, James, Suzan and Jon experienced a high degree of agency within their work. Although most of them experience room provided by the school to pursue their own goals, all of them play a considerably active role in making use of such space and creating it themselves, for instance by taking initiatives, enforcing possibilities, adapting activities in their work to their own wishes, and investing in their professional development. This was expressed by Suzan in the following quotation:

I have to be honest; I think that my colleagues see me as the one that regularly pushes things through, as that is the only way to get things done (semistructured interview).

These five teachers seemed mainly to follow their own direction without caring much about the direction their colleagues want to follow. Jon said:

In my opinion you have to work as a team and operate as a team and together you have to do it. And now I'm like, I'm finding my own way and doing my own things (semi-structured interview).

All mentioned that they sometimes experience hindrances or frustrations, because their school in some way restricts the opportunities to work according to their own goals.

Five teachers, George, Alice, Hugo, Steven and Mark, experienced a moderate degree of agency within their work. All of them experienced room provided by their school to pursue their own goals, make use of this room and also actively search for possibilities. Contrary to the teachers with a high degree of agency, however, these 
Ketelaar, Beijaard, Boshuizen, Den Brok | Teachers' positioning towards an educational innovation in the light of ownership, sense-making and agency

teachers seem to accept more easily or show more understanding of the boundaries the school sets in relation to their working according to their own goals. George explained:

I use the room there is, but I limit myself to the room there is (semi-structured interview).

Also, especially Alice and Mark seemed to be partly led by the opinions or the positions of their colleagues.

One teacher, Ben, experienced a low degree of agency within his work as a teacher. He mainly does what the school expects of him and does not really have a vision of his own. He adapts himself to the demands and goals of the school.

When you start working at this school they tell you we expect this and this from you. And you adjust yourself to that. And I don't have totally a vision of my own on that; I follow that (semi-structured interview).

In his opinion it is not good to change things individually. Instead he always prefers to discuss everything with the team. In that case he also wants to be heard in the discussion.

Overall, except for one teacher, the teachers in this study experienced a relatively high degree of agency within their work as teachers. Teachers experiencing a high degree of agency indicated, however, that they were frustrated or hindered sometimes by the organisation or their colleagues in pursuing their own goals, which was not mentioned by teachers experiencing a moderate or low degree of agency. Furthermore, teachers experiencing a moderate or low degree of agency seemed more often to be influenced in some way by their colleagues than were teachers experiencing a high degree of agency.

\subsection{Relations between teachers' feelings of ownership, sense-making, and experiences of agency}

In Table 5 the results of the individual concepts are shown in relation to each other. Seven of the 11 teachers, Tom, Eric, James, Suzan, Jon, George and Steven, are positioned towards the upper left corner of the table, meaning that they felt a high degree of ownership towards the coaching role, experienced a moderate to high degree of agency in their work, and made sense of the coaching role mainly through assimilation, accommodation or both. The other four teachers, Alice, Hugo, Ben and Mark, are positioned more towards the bottom right corner of the table, meaning that 
Ketelaar, Beijaard, Boshuizen, Den Brok | Teachers' positioning towards an educational innovation in the light of ownership, sense-making and agency

they felt a moderate to low degree of ownership towards the coaching role, experienced a moderate to low degree of agency in their work as teachers, and made sense of the coaching role mainly through a combination of assimilation and distantiation, and toleration and distantiation.

Table 5

Relations between teachers' feelings of ownership, sense-making, and experiences of agency

\begin{tabular}{llll}
\hline \multirow{2}{*}{ Agency } & \multicolumn{3}{c}{ Ownership } \\
\cline { 2 - 4 } High & High & Moderate & Low \\
\multirow{2}{*}{ Moderate } & As (4) & & \\
Low & As - Ac (1) & As - D (1) & T - D (1) \\
& Ac (1) & & T - D (1) \\
\hline
\end{tabular}

Note. $A s=$ assimilation; $A c=$ accommodation; $T=$ toleration; $D=$ distantiation

In general, the teachers positioned at the top left of the table seemed to be more occupied with their students' overall competence development and well-being, whereas the teachers positioned in the bottom right seemed mainly to be focused on their students' competence development within the technical area they teach. Although within the whole group of participants there are some teachers with only a little teaching experience, it is noteworthy that the two teachers positioned mostly in the bottom right corner, Ben and Mark, both had only 1.5 years of teaching experience at the time of data collection.

\section{Conclusion and discussion}

This study investigated teacher change towards a coaching role through the lens of teachers' ownership, sense-making, and agency. More specifically, these three concepts were used to describe and compare SVE teachers' ways of positioning themselves towards the coaching role. The findings indicate that these three concepts are useful for describing similarities and differences in terms of how teachers position themselves towards an innovation. Within the group of 11 teachers who participated in this study considerable differences were found in the extent to which they felt ownership towards the coaching role, in the way they made sense of the coaching role and in their experiences of agency in their work. When relating the findings of these 11 teachers, 
Ketelaar, Beijaard, Boshuizen, Den Brok | Teachers' positioning towards an educational innovation in the light of ownership, sense-making and agency

there is a tendency noticeable within this group that those who experienced a moderate to high degree of agency within their work, felt a high degree of ownership with regard to the coaching role, but only when making sense of the coaching role through processes of assimilation and/or accommodation. This might also indicate that a moderate to high degree of agency does not necessarily lead to an innovative teacher, but can result in a teacher who uses his or her agency to reject the innovation, which seemed to be the case with Mark.

This last conclusion seems to partly contradict Pierce et al. (2001), who suggested that the amount of control someone has over something relates positively to the degree to which he or she feels ownership towards it. Mark experienced a moderate degree of agency within his work, but felt a low degree of ownership towards the coaching role and made sense of it mainly through the processes of toleration and distantiation. He seemed to use his experience of agency in his work to offer resistance to the innovation, because the innovation conflicted with his identity as a teacher. Sannino (2010) explained, however, that resistance to an innovation is not necessarily something negative, but can be a sign of involvement and development. This might also be the case for Mark and Ben; for both of them their students' well-being was the basis for their opinion about the coaching role. These two beginning teachers believe that the coaching role means that teachers are no longer allowed to provide students with the support, guidance and structure, which they think their students really need. Yet, most teachers who were positive about the coaching role emphasised the importance of exactly these elements in coaching. Day and Smethem (2009) state that 'although young teachers may be more open to change, they can lack the experience, competence and confidence to fully comprehend and implement change' (p. 149). The beginning teachers in this study might have had less knowledge about the coaching role and how to bring it into practice. This could explain their lack of ownership, as the more a teacher knows about an innovation the deeper his or her relationship with that innovation may be and the stronger their feelings of ownership towards it (Pierce et al., 2001). In teacher education there should therefore be more attention to recent educational innovations that ask for a different pedagogy, in this case more of a coaching role.

A lack of knowledge could not only be assigned to the two teachers with sparse teaching experience. Several other teachers who made sense of the coaching role through the process of assimilation, accommodation, or both, mentioned a lack of clarity about the meaning of the coaching role. Fullan (2007) emphasises the importance of clarity about the goals and means of an innovation, because otherwise teachers simply do not know how to put it into practice. This can lead to what he calls 
Ketelaar, Beijaard, Boshuizen, Den Brok | Teachers' positioning towards an educational innovation in the light of ownership, sense-making and agency

false clarity: an oversimplification of the innovation, which may result in teachers thinking that they are already working according to the innovation. In the light of the results of this study, a lack of clarity about the coaching role might force teachers more or less to make sense of it from the perspective of their own frame of reference. Although in the case of assimilation there is a match between the teacher's frame of reference and that of the innovation, at the same time important aspects of the innovation can get lost in the individual interpretation of the teacher (Luttenberg et al., 2009).

Several teachers in this study, especially teachers feeling a high degree of ownership, experienced a lack of opportunities for collaboration and a lack of interest for the coaching role among their colleagues. A lack of collaboration can lead to individual values and beliefs which in turn can lead either to enactment of traditions, lowering expectations, or to innovating alone (McLaughlin \& Talbert, 2001). This seems to be especially the case in school 2, where teachers wanting to develop the coaching role and put it into practice lack connection with their colleagues and possibilities to collaborate, whereas teachers preferring to continue teaching in the way they are accustomed to are able to do so.

An explanation for this lack of connection with colleagues might be what Pierce at al. (2003) call the dark side of ownership. These teachers may unconsciously act too possessively about the innovation and therefore shut out their colleagues. This 'dark side' could also be found in agency. When teachers are experiencing a high degree of agency in their work it could lead to everybody doing it their own way. This asks for good leadership consisting of giving teachers enough room to put their ideas into practice in ways that fit their professional identity and, at the same time, providing teachers with guidelines and boundaries within which they can operate (Fullan, 2007).

From the results of this study several practical implications can be derived. First, this study shows that an educational innovation initiated by the government does not necessarily evoke resistance. If teachers' frames of reference correspond with the frame of reference of the innovation, and they experience enough agency to be able to find their own way in putting the innovation into practice, they can feel a high degree of ownership regarding the innovation. Second, the importance of collaboration in the implementation process of an innovation became clear. Collaboration could help teachers putting up resistance to the innovation to talk about the conflicts they experience between the innovation and their own beliefs, which could also elucidate the similarities instead of only the differences (Sannino, 2010). Also, it can lead to more information and better knowledge about the innovation, which can strengthen feelings of ownership (Pierce et al., 2001). Collaboration may also help to prevent teachers from 
Ketelaar, Beijaard, Boshuizen, Den Brok | Teachers' positioning towards an educational innovation in the light of ownership, sense-making and agency

wandering towards the dark side of ownership, sense-making and agency, and ending up on an 'island' within their school where nobody can reach them anymore. A school in an innovation process therefore needs a school leader who stimulates collaboration and at the same time respects the different identities of individual teachers.

This study has several limitations, but offers opportunities for further research. The teachers participated on a voluntary basis, which may explain why most of them had a moderate to high degree of ownership and that there was correspondence between their own frame of reference and the innovation: voluntary participation in a time-consuming study such as this one means it is likely that those with less favourable opinions about the innovation refused to participate in the study or dropped out. Furthermore, generalisation of the results is difficult as only a small number of SVE teachers participated, all teaching in the technology education sector. Teachers from sectors other than technology should be studied, because they and their students might respond differently towards innovations and towards the coaching role in particular. To be able to generalise more, it would also be useful to study the concepts of ownership, sense-making and agency in different contexts and maybe on a larger

scale. Finally, studying these three concepts longitudinally could be useful in order to explore whether they change and, if so, what causes change.

\section{References}

Bakker, M. (2008). Design and evaluation of video portfolios: reliability, generalizability, and validity of an authentic performance assessment for teachers [Doctoral dissertation]. Leiden: Leiden University Graduate School of Teaching (ICLON).

Beijaard, D. (2009). Leraar worden en leraar blijven: over de rol van identiteit in professioneel leren van beginnende docenten [Becoming a teacher and staying a teacher: about the role of identity in professional development of beginning teachers]. Inaugural lecture. Eindhoven University of Technology.

Beijaard, D., Meijer, P. C., \& Verloop, N. (2004). Reconsidering research on teachers' professional identity. Teaching and Teacher Education, 20(2), 107-128.

Bergen, T., \& Van Veen, K. (2004). Het leren van leraren in een context van onderwijsvernieuwingen: waarom is het zo moeilijk? [Teacher learning in the context of educational innovations: why is it so difficult?]. VELON: Tijdschrift voor Lerarenopleiders, 25(4), 29-39.

Biemans, H., Nieuwenhuis, L., Poell, R., Mulder, M., \& Wesselink, R. (2004). Competence-based VET in the Netherlands: background and pitfalls. Journal of Vocational Education \& Training, 56(4), 523-538. 
Ketelaar, Beijaard, Boshuizen, Den Brok | Teachers' positioning towards an educational innovation in the light of ownership, sense-making and agency

Biemans, H., Wesselink, R., Gulikers, J., Schaafsma, S., Verstegen, J., \& Mulder, M. (2009). Towards competence-based VET: dealing with the pitfalls. Journal of Vocational Education \& Training, 61(3), 267-286.

Breiting, S. (2008). Mental ownership and participation for innovation in environmental education and education for sustainable development. In A. Reid, B. B. Jensen, J. Nikel \& V. Simovska (Eds.), Participation and Learning (pp. 159-180). Dordrecht: Springer.

Coldron, J., \& Smith, R. (1999). Active location in teachers' construction of their professional identities. Journal of Curriculum Studies, 31(6), 711-726.

Day, C., Sammons, P., Stobart, G., Kington, A., \& Gu, Q. (2007). Teachers matter: Connecting lives, work and effectiveness. Maidenhead: Open University Press.

Day, C., \& Smethem, L. (2009). The effects of reform: Have teachers really lost their sense of professionalism? Journal of Educational Change, 10(2), 141-157.

De Bruijn, E., \& Leeman, Y. (2011). Authentic and self-directed learning in vocational education: Challenges to vocational educators. Teaching and Teacher Education, 27, 694-702.

Dutch Inspectorate of Education (2007). Competenties: kun je dat leren? Een inspectieonderzoek naar de onderwijskundige kwaliteit van de vernieuwing in het mbo [Competencies: can you learn it? An inspectorate research into the educational quality of the innovation in SVE]. Retrieved from http://www.onderwijsinspectie.nl/binaries/content/assets/Actueel_publicaties/ 2007/Competenties+kun+je+dat+leren.pdf

Fullan, M. (2007). The new meaning of educational change. New York, NY: Teachers College Press.

Iredale, A., \& Schoch, J. (2010). Coaching. In J. Avis, R. Fisher \& R. Thompson (Eds.), Teaching in lifelong learning (pp. 206-212). Berkshire: Open University Press.

Ketelaar, E., Beijaard, D., Den Brok, P. J., Boshuizen, H. P. A. (2009). Teachers' coaching role in competence-based VET. An exploratory study on the state of affairs. Paper presented at ISATT conference, Rovaniemi, Finland.

Lasky, S. (2005). A sociocultural approach to understanding teacher identity, agency and professional vulnerability in a context of secondary school reform. Teaching and Teacher Education, 21(8), 899-916.

Le Cornu, R., \& Peters, J. (2005). Towards constructivist classrooms: the role of the reflective teacher. Journal of Educational Enquiry, 6(1), 50-64.

Luttenberg, J., Imants, J., Van Veen, K., \& Carpay, T. (2009). Zoeken naar samenhang. De rol van 'betekenisafstemming' in de interactie tussen docent en vernieuwing 
Ketelaar, Beijaard, Boshuizen, Den Brok | Teachers' positioning towards an educational innovation in the light of ownership, sense-making and agency

[Looking for coherence. The role of sensemaking in the interaction between teacher and innovation]. Pedagogische Studiën, 86, 443-458.

Lyle, J. (2003). Stimulated Recall: a report on its use in naturalistic research. British Educational Research Journal, 29(6), 861-878.

Marshall, B., \& Drummond, M. J. (2006). How teachers engage with assessment for learning: lessons from the classroom. Research Papers in Education, 21(2), 133149.

McLaughlin, M. W., \& Talbert, J. E. (2001). Professional communities and the work of high school teaching. Chicago, IL: University of Chicago Press.

Meijer, P. C., Verloop, N., \& Beijaard, D. (2002). Multi-method triangulation in a qualitative study on teachers' practical knowledge: An attempt to increase internal validity. Quality \& Quantity, 36, 145-167.

Metcalfe, J., \& Greene, M. J. (2007). Metacognition of agency. Journal of Experimental Psychology: General, 136(2), 184-199.

Miles, M. B., \& Huberman, A. M. (1994). Qualitative data analysis: An expanded sourcebook. Thousand Oaks, CA: SAGE.

Nickolaus, R., Knoll, B., \& Gschwendtner, T. (2007). Innovations in vocational education and difficulties in their empirical substantiation. European Journal of Vocational Training, 40, 22.

Pierce, J. L., Kostova, T., \& Dirks, K. T. (2001). Toward a theory of psychological ownership in organizations. Academy of Management Review, 26(2), 298-310.

Pierce, J. L., Kostova, T., \& Dirks, K. T. (2003). The state of psychological ownership: Integrating and extending a century of research. Review of General Psychology, 7(1), 84-107.

Sannino, A. (2010). Teachers' talk of experiencing: Conflict, resistance and agency. Teaching and Teacher Education, 26(4), 838-844.

Spillane, J., Reiser, B., \& Reimer, T. (2002). Policy implementation and cognition: Reframing and refocusing implementation research. Review of Educational Research, 72(3), 387.

Struckman, C. K., \& Yammarino, F. J. (2003). Organizational change: A categorization scheme and response model with readiness factors. Research in Organizational Change and Development, 14, 1-50.

Struyven, K., \& De Meyst, M. (2010). Competence-based teacher education: Illusion or reality? An assessment of the implementation status in Flanders from teachers' and students' points of view. Teaching and Teacher Education, 26, 1495-1510. 
Ketelaar, Beijaard, Boshuizen, Den Brok | Teachers' positioning towards an educational innovation in the light of ownership, sense-making and agency

Vähäsantanen, K., Hökkä, P., Eteläpelto, A., Rasku-Puttonen, H., \& Littleton, K. (2008). Teachers' professional identity negotiations in two different work organisations. Vocations and Learning, 1(2), 131-148.

Vähäsantanen, K., \& Eteläpelto, A. (2009). Vocational teachers in the face of a major educational reform: individual ways of negotiating professional identities. Journal of Education and Work, 22(1), 15-33.

Van den Berg, J., \& Geurts, J. (2007). Leren van innoveren: vijf sleutels voor succes [Learning through innovation: five keys to success]. 's-Hertogenbosch: CINOP.

Van Veen, K., \& Lasky, S. (2005). Emotions as a lens to explore teacher identity and change: Different theoretical approaches. Teaching and Teacher Education, 21(8), 895-898.

Velde, C. (1999). An alternative conception of competence: implications for vocational education. Journal of Vocational Education \& Training, 51(3), 437-447.

Vermunt, J., \& Verloop, N. (1999). Congruence and friction between learning and teaching. Learning and instruction, 9(3), 257-280.

Wesselink, R., Biemans, H. J. A., Mulder, M., \& van den Elsen, E. R. (2007). Competence-based VET as seen by Dutch researchers. European Journal of Vocational Training, 4O(1), 38-51.

Yin, R. K. (2003). Case study research. Design and methods. Thousand Oaks, CA: SAGE.

Yu, C., \& Boulton-Lewis, G. (2008). Hong Kong secondary business teachers' conceptions of student competence and ways of teaching. Journal of Vocational Education and Training, 60(3), 257-272.

Zimmerman, B. (2002). Becoming a self-regulated learner: An overview. Theory Into Practice, 41(2), 64-70.

Zsiga, P., \& Webster, M. (2007). Why should secondary educators be interested in selfdirected learning? International Journal of Self-Directed Learning, 4(2), 58-68. 